\title{
Calcium dynamics in catecholamine-containing secretory vesicles
}

\author{
Alfredo Moreno ${ }^{\text {a }}$, Carmen D. Lobatón ${ }^{\text {a }}$, Jaime SantoDomingo a , Laura Vay a ${ }^{\text {, Esther }}$ \\ Hernández-SanMiguel $^{\mathrm{a}}$, Rosario Rizzuto ${ }^{\mathrm{b}}$, Mayte Montero ${ }^{\mathrm{a}}$, Javier Alvarez ${ }^{\mathrm{a}, *}$ \\ a Instituto de Biología y Genética Molecular (IBGM), Departamento de Bioquímica y Biología Molecular y Fisiología, Facultad de Medicina, \\ Universidad de Valladolid and Consejo Superior de Investigaciones Científicas (CSIC), Ramón y Cajal 7, E-47005 Valladolid, Spain \\ b Experimental and Diagnostic Medicine Section of General Pathology, University of Ferrara, 44100 Ferrara, Italy
}

Received 19 October 2004; received in revised form 17 February 2005; accepted 21 February 2005

Available online 8 April 2005

\begin{abstract}
We have used an aequorin chimera targeted to the membrane of the secretory granules to monitor the free $\left[\mathrm{Ca}^{2+}\right]$ inside them in neurosecretory PC12 cells. More than $95 \%$ of the probe was located in a compartment with an homogeneous $\left[\mathrm{Ca}^{2+}\right]$ around $40 \mu \mathrm{M}$. Cell stimulation with either ATP, caffeine or high- $\mathrm{K}^{+}$depolarization increased cytosolic $\left[\mathrm{Ca}^{2+}\right]$ and decreased secretory granule $\left[\mathrm{Ca}^{2+}\right]\left(\left[\mathrm{Ca}^{2+}\right]_{\mathrm{SG}}\right)$. Inositol-(1,4,5)trisphosphate, cyclic ADP ribose and nicotinic acid adenine dinucleotide phosphate were all ineffective to release $\mathrm{Ca}^{2+}$ from the granules. Changes in cytosolic $\left[\mathrm{Na}^{+}\right](0-140 \mathrm{mM})$ or $\left[\mathrm{Ca}^{2+}\right](0-10 \mu \mathrm{M})$ did not modify either $\left(\left[\mathrm{Ca}^{2+}\right]_{\mathrm{SG}}\right)$. Instead, $\left[\mathrm{Ca}^{2+}\right]_{\mathrm{SG}}$ was highly sensitive to changes in the $\mathrm{pH}$ gradient between the cytosol and the granules. Both carbonyl cyanide 4-(trifluoromethoxy)phenylhydrazone (FCCP) and nigericin, as well as cytosolic acidification, reversibly decreased $\left[\mathrm{Ca}^{2+}\right]_{\mathrm{SG}}$, while cytosolic alcalinization reversibly increased $\left[\mathrm{Ca}^{2+}\right]_{\mathrm{SG}}$. These results are consistent with the operation of a $\mathrm{H}^{+} / \mathrm{Ca}^{2+}$ antiporter in the vesicular membrane. This antiporter could also mediate the effects of ATP, caffeine and high- $\mathrm{K}^{+}$on $\left[\mathrm{Ca}^{2+}\right]_{\mathrm{SG}}$, because all of them induced a transient cytosolic acidification. The FCCP-induced decrease in $\left[\mathrm{Ca}^{2+}\right]_{\mathrm{SG}}$ was reversible in 10-15 min even in the absence of cytosolic $\mathrm{Ca}^{2+}$ or ATP, suggesting that most of the calcium content of the vesicles is bound to a slowly exchanging $\mathrm{Ca}^{2+}$ buffer. This large store buffers $\left[\mathrm{Ca}^{2+}\right]_{\mathrm{SG}}$ changes in the long-term but allows highly dynamic free $\left[\mathrm{Ca}{ }^{2+}\right]_{\mathrm{SG}}$ changes to occur in seconds or minutes.
\end{abstract}

(C) 2005 Elsevier Ltd. All rights reserved.

Keywords: Calcium; Secretory vesicles; PC12; Catecholamine; Aequorin

\section{Introduction}

Secretory vesicles constitute one of the less known intracellular $\mathrm{Ca}^{2+}$ pools. It has been known for more than 20 years that they contain large amounts of total calcium (20-60 mM), in particular chromaffin granules of the adrenal medulla and zymogen granules of the exocrine pancreas [1-3]. In addition, chromaffin granules contain also large amounts of proteins $(100 \mathrm{mg} / \mathrm{ml}$, of which $40 \%$ is chromo-

Abbreviations: $\left[\mathrm{Ca}^{2+}\right]_{\mathrm{SG}}$, secretory granule $\left[\mathrm{Ca}^{2+}\right] ;\left[\mathrm{Ca}^{2+}\right]_{\mathrm{c}}$, cytosolic $\left[\mathrm{Ca}^{2+}\right]$; cADPR, cyclic ADP ribose; EGFP, enhanced green fluorescent protein; FCCP, carbonyl cyanide 4-(trifluoromethoxy)phenylhydrazone; InsP $\mathrm{P}_{3}$, inositol-(1,4,5)-trisphosphate; NAADP, nicotinic acid adenine dinucleotide phosphate; VAMP, vesicle-associated membrane protein; VAMP-mutaeq, VAMP-mutated aequorin chimera

* Corresponding author. Tel.: +34 983 423085; fax: +34 983423588.

E-mail address: jalvarez@ibgm.uva.es (J. Alvarez). granin A), catecholamines $(0.5-0.6 \mathrm{M})$ and ATP $(130 \mathrm{mM})$ $[2,4]$. The physiological significance of intragranular $\mathrm{Ca}^{2+}$ $\left(\left[\mathrm{Ca}^{2+}\right]_{\mathrm{SG}}\right)$ within these densely packed vesicles, either to play a role in secretion, to be destined for secretion or just structural to keep granule contents together, is still obscure. Similarly, the mechanisms for $\mathrm{Ca}^{2+}$ uptake and release from the granules are poorly known or controversial and may be different depending on the cell type [5-9].

Recently, using a vesicle-associated membrane protein (VAMP)-aequorin chimera targeted to the membrane of the secretory vesicles, it was possible for the first time to monitor the intragranular $\left[\mathrm{Ca}^{2+}\right]$ in MIN6 $\beta$-cells [8]. Intragranular free $\left[\mathrm{Ca}^{2+}\right]$ was around $50 \mu \mathrm{M}, \mathrm{Ca}^{2+}$ was accumulated into the vesicles via a P-type $\mathrm{Ca}^{2+}$-ATPase and released through ryanodine receptors and nicotinic acid adenine dinucleotide phosphate (NAADP) receptors $[8,9]$. We have used here the same VAMP-aequorin chimera to monitor the dynamics of 
$\left[\mathrm{Ca}^{2+}\right]$ in the catecholamine-containing secretory granules of neurosecretory PC12 cells. Our results show that, although the free $\left[\mathrm{Ca}^{2+}\right]$ is similar to that found in MIN6 $\beta$-cells, the mechanisms of $\mathrm{Ca}^{2+}$ uptake and release and the response to extracellular stimuli are largely different.

\section{Experimental procedures}

\subsection{Cell culture and transfection}

The construction strategy of the 2-synaptobrevin-mutated aequorin (VAMP-mutaeq) chimera has been described previously [8]. PC12 rat pheochromocytoma cells were grown in Dulbecco's Modified Eagle's Medium supplemented with $7.5 \%$ fetal calf serum, $7.5 \%$ horse serum and $2 \mathrm{mM}$ glutamine. The construct for cytosolic aequorin has been also described previously [10]. The VAMP-enhanced green fluorescent protein (EGFP) construct was made by inserting in frame the VAMP sequence in the HindIII site of the pEGFP-N1 plasmid. Transfections were carried out using Metafectene (Biontex, Germany) or ExGen500 (Fermentas, Germany).

\section{2. $\left[\mathrm{Ca}^{2+}\right]_{M}$ and $\left[\mathrm{Ca}^{2+}\right]_{c}$ measurements with aequorin}

PC12 cells plated onto $13 \mathrm{~mm}$ plastic round coverslips were transiently transfected with the corresponding plasmid. For aequorin reconstitution, PC12 cells expressing cytosolic aequorin were incubated for $1-2 \mathrm{~h}$ at room temperature with $1 \mu \mathrm{M}$ of wild-type coelenterazine, and cells expressing VAMP-mutaeq were incubated for $1-2 \mathrm{~h}$ at room temperature with $1 \mu \mathrm{M}$ of coelenterazine $\mathrm{n}$, in standard medium (145 mM NaCl, $5 \mathrm{mM} \mathrm{KCl}, 1 \mathrm{mM} \mathrm{MgCl}_{2}, 1 \mathrm{mM} \mathrm{CaCl}_{2}$, $10 \mathrm{mM}$ glucose and $10 \mathrm{mM}$ Hepes, $\mathrm{pH}$ 7.4). Cells were then placed in the perfusion chamber of a purpose-built luminometer thermostatized at $37^{\circ} \mathrm{C}$. For experiments with permeabilized cells, cells expressing VAMP-mutaeq were reconstituted with $1 \mu \mathrm{M}$ coelenterazine $\mathrm{n}$ for $1-2 \mathrm{~h}$ and then placed in the luminometer as above. Then, standard medium containing $0.5 \mathrm{mM}$ EGTA instead of $\mathrm{Ca}^{2+}$ was perfused for $1 \mathrm{~min}$, followed by $1 \mathrm{~min}$ of intracellular medium $(130 \mathrm{mM}$ $\mathrm{KCl}, 10 \mathrm{mM} \mathrm{NaCl}, 1 \mathrm{mM} \mathrm{MgCl} 2,1 \mathrm{mM} \mathrm{K} \mathrm{PO}_{4}, 0.5 \mathrm{mM}$ EGTA, $1 \mathrm{mM}$ ATP, $20 \mu \mathrm{M}$ ADP, $2 \mathrm{mM}$ succinate and $20 \mathrm{mM}$ Hepes, $\mathrm{pH}$ 7) containing $20 \mu \mathrm{M}$ digitonin. Then, intracellular medium without digitonin and containing $100 \mathrm{nM}\left[\mathrm{Ca}^{2+}\right]$ (prepared with an EGTA/ $\mathrm{Ca}^{2+}$ mixture) was perfused. Control experiments performed in PC12 cells expressing mitochondrially targeted mutated aequorin showed that this permeabilization procedure rendered all the mitochondrial space accessible to the perfusion medium (data not shown). Calibration of the luminescence data into $\left[\mathrm{Ca}^{2+}\right]$ was made using an algorithm as previously described [11].

\subsection{Confocal measurements}

PC12 cells expressing VAMP-EGFP were imaged on a BioRad Radiance 2000 confocal spectrophotometer using a
$60 \times$ oil immersion objective mounted in a Nikon Eclipse TE2000 microscope. Cells were also loaded with $50 \mathrm{nM}$ lysotracker red for $1 \mathrm{~min}$ at room temperature and imaged sequentially for both EGFP and lysotracker red. EGFP was excited with the $488 \mathrm{~nm}$ line of the Argon laser, and the fluorescence emitted between 500 and $530 \mathrm{~nm}$ was collected. In the case of lysotracker red, the fluorescence excited with the $543 \mathrm{~nm}$ line of the green $\mathrm{He}-\mathrm{Ne}$ laser and emitted between 570 and $700 \mathrm{~nm}$ was measured.

\subsection{Measurement of cytosolic $\mathrm{pH}$}

$\mathrm{pH}$ measurements were carried out by microfluorimetry of bcecf-loaded HeLa cells. Cells were loaded with bcecf by incubation with $0.8 \mu \mathrm{M}$ bcecf-AM for $30 \mathrm{~min}$ at $30^{\circ} \mathrm{C}$. Then, the dye was washed out and cells were incubated for $30 \mathrm{~min}$ at $30^{\circ} \mathrm{C}$ before mounting into the perfusion chamber of an Axiovert 200 microscope. Single cell fluorescence was excited at 490 and $440 \mathrm{~nm}$ using a Cairn monochromator. A pair of images was taken every $2 \mathrm{~s}$ by a Hamamatsu ORCA-ER camera and ratioed after background substraction using the Metafluor program (Universal Imaging). Experiments were performed at $37{ }^{\circ} \mathrm{C}$. For calibration of $\mathrm{pH}$ measurements, solutions containing $150 \mathrm{mM} \mathrm{KCl}, 10 \mathrm{mM}$ Hepes, $10 \mathrm{mM}$ glucose, $1 \mathrm{mM} \mathrm{CaCl}_{2}, 1 \mathrm{mM} \mathrm{MgCl}_{2}, 5 \mu \mathrm{M}$ nigericin and $\mathrm{pH}$ 6.6, 7.0 or 7.4 were perfused at the end of every experiment.

\subsection{Materials}

Wild-type coelenterazine, coelenterazine n, lysotracker red and bcecf-AM were obtained from Molecular Probes, OR, USA. Bafilomycin A was from LC laboratories, Woburn, MA, USA or from Sigma, Madrid. Inositol-(1,4,5)trisphosphate (InsP $\mathrm{P}_{3}$ ), cyclic ADP ribose (cADPR), nicotinic acid adenine dinucleotide phosphate (NAADP), carbonyl cyanide 4-(trifluoromethoxy)phenylhydrazone (FCCP) and nigericin were from Sigma, Madrid. Other reagents were from Sigma, Madrid or Merck, Darmstadt.

\section{Results}

\subsection{Targeting of VAMP-mutaeq in PC12 cells}

The specificity of targeting of the VAMP-mutaeq chimera to secretory vesicles has been previously shown by immunofluorescence and immunoelectron microscopy in insulin containing secretory vesicles of MIN6 $\beta$-cells [8]. We have used here a VAMP-EGFP chimera to investigate the targeting of the probe in PC12 cells. Fig. 1 (left panels) shows confocal images of the fluorescence of a PC12 cell expressing VAMP-EGFP at three different planes. The pattern is typically granular and consistent with the targeting to the secretory granules. In addition, VAMP-EGFP colocalizes with the marker for acidic compartments lysotracker red. The middle panels show the fluorescence of lysotracker red obtained in 

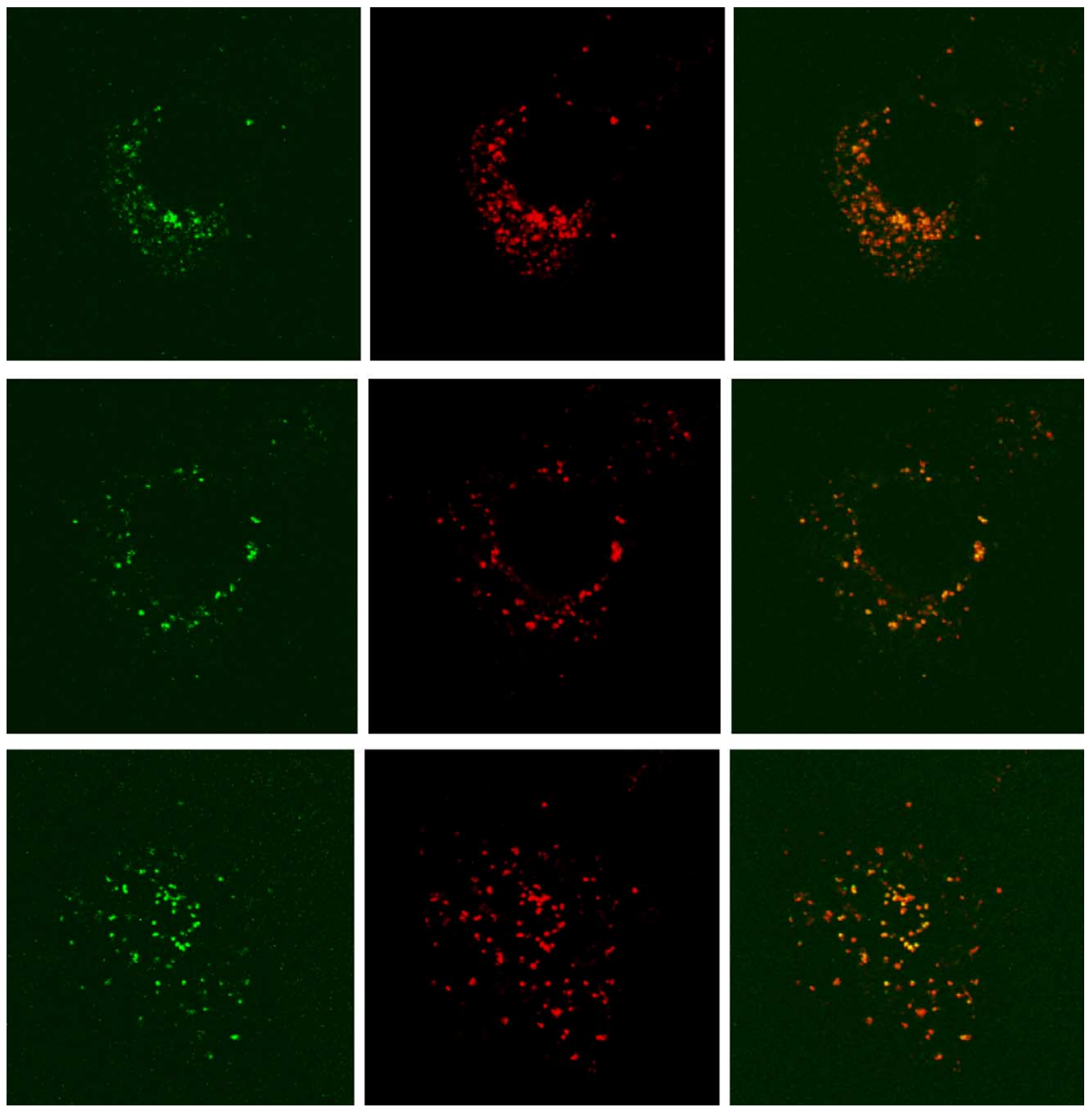

Fig. 1. Confocal fluorescence co-localization of VAMP-EGFP and lysotracker red in PC12 cells. PC12 cells expressing VAMP-EGFP were loaded with lysotracker red as described in Section 2. The left panels show three different confocal planes of the fluorescence of VAMP-EGFP. The middle panels show the fluorescence of lysotracker red in the same confocal planes. The right panels show the overlap of both fluorescence images.

the same confocal planes and the right panels show that the fluorescences of both VAMP-EGFP and lysotracker red are mostly overlapping.

Although the VAMP-EGFP fluorescence images suggest that the probe is correctly targeted to secretory granules also in PC12 cells, it is difficult to estimate from these images if there may be a small percentage of the chimera in a different location. To investigate this point, we have used the properties of aequorin to determine the degree of homogeneity of the $\left[\mathrm{Ca}^{2+}\right]$ in the compartment expressing VAMP-mutaeq. Emission of light by aequorin is irreversible from an exper- imental point of view. Thus, aequorin is being continuously consumed along the experiments at a rate which is highly dependent on the local $\left[\mathrm{Ca}^{2+}\right]$. When aequorin is distributed in compartments with different $\left[\mathrm{Ca}^{2+}\right]$, it will be consumed faster in those compartments with higher $\left[\mathrm{Ca}^{2+}\right]$. This can be easily detected and quantified in the aequorin luminescence records, and this property has been used previously to estimate the presence and size of compartments with different $\left[\mathrm{Ca}^{2+}\right]$ in mitochondria and endoplasmic reticulum $[12,13]$.

Fig. 2 (upper panel) shows a crude record of luminescence in PC12 cells expressing VAMP-mutaeq. As in the previous 

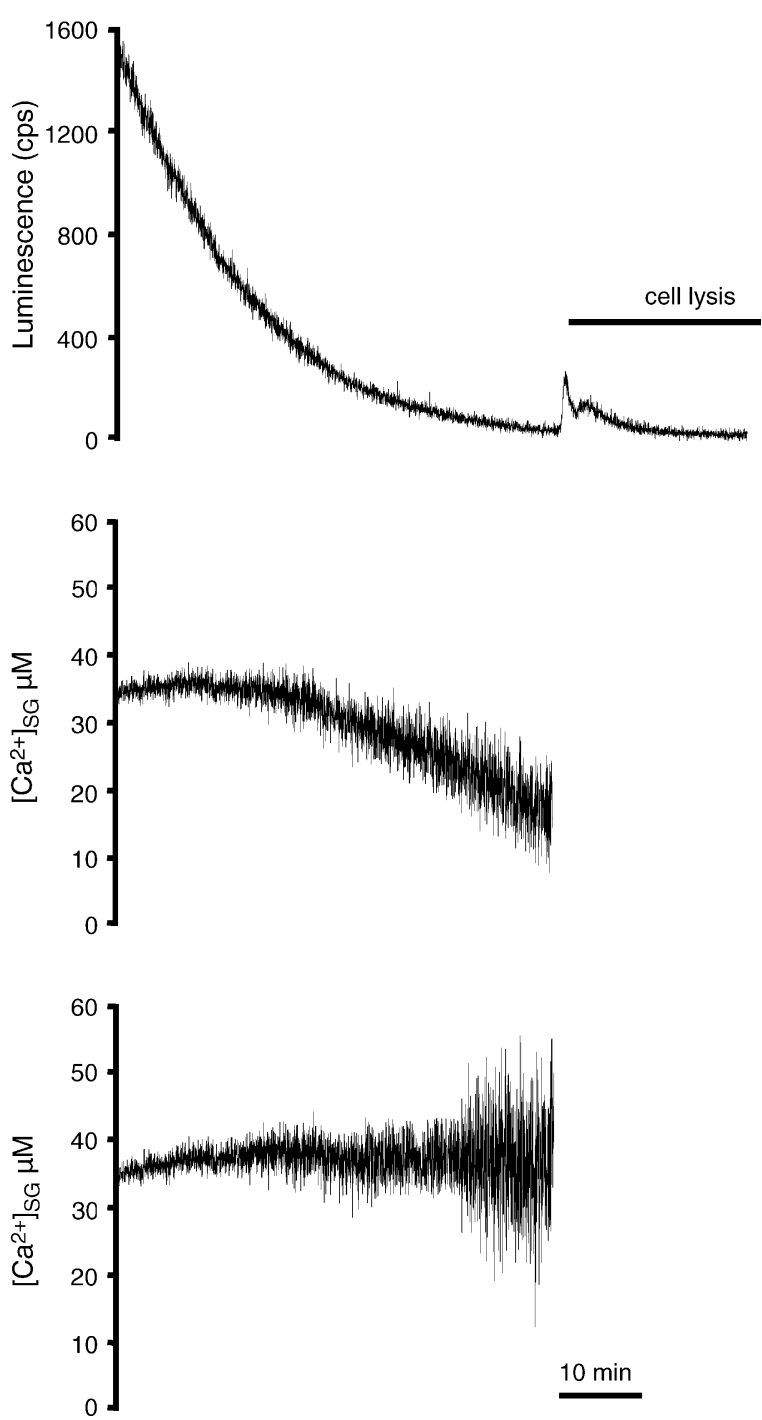

Fig. 2. Steady-state $\left[\mathrm{Ca}^{2+}\right]$ in the secretory granules. PC12 cells expressing VAMP-aequorin were reconstituted with coelenterazine $\mathrm{n}$ as described in Section 2 and then the aequorin luminescence was monitored under continuous perfusion with external medium. Upper panel: crude luminescence record. When indicated "cell lysis", standard medium containing $100 \mu \mathrm{M}$ digitonin and $10 \mathrm{mM} \mathrm{Ca}^{2+}$ was perfused. Middle panel: calibrated $\left[\mathrm{Ca}^{2+}\right]$ values from the same experiment. Lower panel: calibrated $\left[\mathrm{Ca}^{2+}\right]$ values from the same experiment obtained not taking into account the final $3.5 \%$ of the emitted luminescence. This experiment is representative of seven similar ones.

work in MIN6 $\beta$-cells, we have reconstituted VAMP-mutaeq expressing cells with coelenterazine $\mathrm{n}$ in order to measure the high- $\left[\mathrm{Ca}^{2+}\right]$ presumably contained within the secretory granules. However, we have preferred to avoid $\mathrm{Ca}^{2+}$-depletion of the secretory granules prior to the measurements, by two reasons: (i) the rate of aequorin consumption at the $\left[\mathrm{Ca}^{2+}\right]$ measured allowed monitoring the $\left[\mathrm{Ca}^{2+}\right]_{\mathrm{SG}}$ during reasonable times (20-30 $\mathrm{min})$ and (ii) it has been described that refilling of the secretory granule $\mathrm{Ca}^{2+}$ store in PC12 cells is extremely slow [3]. Because of the lack of previous $\mathrm{Ca}^{2+}$-depletion, the $\mathrm{Ca}^{2+}$ content of the secretory granules is high at the beginning of the experiment, and the record of luminescence shows a continuously decreasing trend due to aequorin consumption in a high- $\left[\mathrm{Ca}^{2+}\right]$ environment. Once the luminescence had reached nearly zero values, cells were permeabilized with digitonin to reveal all the aequorin luminescence still present in the sample. In case a significant proportion of aequorin was present (due to mistargeting) in compartments having low resting $\left[\mathrm{Ca}^{2+}\right]$, its luminescence should be released here. However, only a small percentage of the total luminescence, below $5 \%(4.3 \pm 0.3 \%$, mean \pm S.E.M., $n=7)$, was released at this point.

Fig. 2 (middle panel) shows the record of $\left[\mathrm{Ca}^{2+}\right]$ calculated from the same experiment. It shows a steady-state $\left[\mathrm{Ca}^{2+}\right]$ level around $35 \mu \mathrm{M}$, which keeps stable for 15-20 min and then starts to decrease slowly. This final decrease is due to the presence of a small percentage of aequorin in a compartment with low- $\left[\mathrm{Ca}^{2+}\right]$. As most of the aequorin present in the high- $\mathrm{Ca}^{2+}$ compartment is being consumed, the relative size of the low-Ca ${ }^{2+}$ compartment increases progressively and this is reflected as a decrease in the calibrated $\left[\mathrm{Ca}^{2+}\right]$ values. The percentage of aequorin present in that low- $\left[\mathrm{Ca}^{2+}\right]$ compartment can be estimated from the relative amount of luminescence emitted after cell permeabilization, that is, less than $5 \%$. In fact, if that percentage of luminescence was not taken into account during the calibration of luminescence into $\left[\mathrm{Ca}^{2+}\right]$ values, the record of calibrated $\left[\mathrm{Ca}^{2+}\right]$ remained stable for nearly $1 \mathrm{~h}$ around $40 \mu \mathrm{M}$ (Fig. 2, lower panel). In this case, calculation of $\left[\mathrm{Ca}^{2+}\right]$ values was made not taking into account the final $3.5 \%$ of the luminescence. In several similar experiments, this percentage was always below $5 \%$. Therefore, these results constitute functional evidence that more than $95 \%$ of our VAMP-mutaeq probe is measuring $\left[\mathrm{Ca}^{2+}\right]$ in a compartment with an homogeneous $\left[\mathrm{Ca}^{2+}\right]$ around $40 \mu \mathrm{M}$ $(43 \pm 3 \mu \mathrm{M}$, mean \pm S.E.M., $n=7)$.

\subsection{Dynamic measurements of $\left[\mathrm{Ca}^{2+}\right]$ in the secretory vesicles}

We have now investigated the effect on the secretory granule $\left[\mathrm{Ca}^{2+}\right]$ of a series of agents known to induce cytosolic $\mathrm{Ca}^{2+}$ transients by different mechanisms: ATP, acting on purinergic receptors, triggers Ins $\mathrm{P}_{3}$ production and release of $\mathrm{Ca}^{2+}$ from the ER; caffeine, acting on ryanodine receptors, induces also $\mathrm{Ca}^{2+}$ release from the ER; and high- $\mathrm{K}^{+}$, by depolarizing the cells, induces $\mathrm{Ca}^{2+}$ entry via plasma membrane voltage-dependent $\mathrm{Ca}^{2+}$ channels. Fig. 3 shows the effects of these stimuli on both cytosolic and secretory granule $\left[\mathrm{Ca}^{2+}\right]$. As expected, all of the stimuli induced transient $\left[\mathrm{Ca}^{2+}\right]$ increases in the cytosol. However, it came as a surprise to see that all of them induced also a transient decrease in the $\left[\mathrm{Ca}^{2+}\right]$ of secretory granules. These results suggested that secretory granules could release $\mathrm{Ca}^{2+}$ during the process of stimulated secretion. To investigate the mechanism of stimulated $\mathrm{Ca}^{2+}$ release from the granules, we used permeabilized cells to test the effects of several second messengers: $\mathrm{InsP}_{3}$, cADPR and NAADP. Fig. 4 shows that none of them produced any change in the $\left[\mathrm{Ca}^{2+}\right]_{\mathrm{sG}}$. Similarly, perfusion of a $10 \mu \mathrm{M}\left[\mathrm{Ca}^{2+}\right]$ buffer 

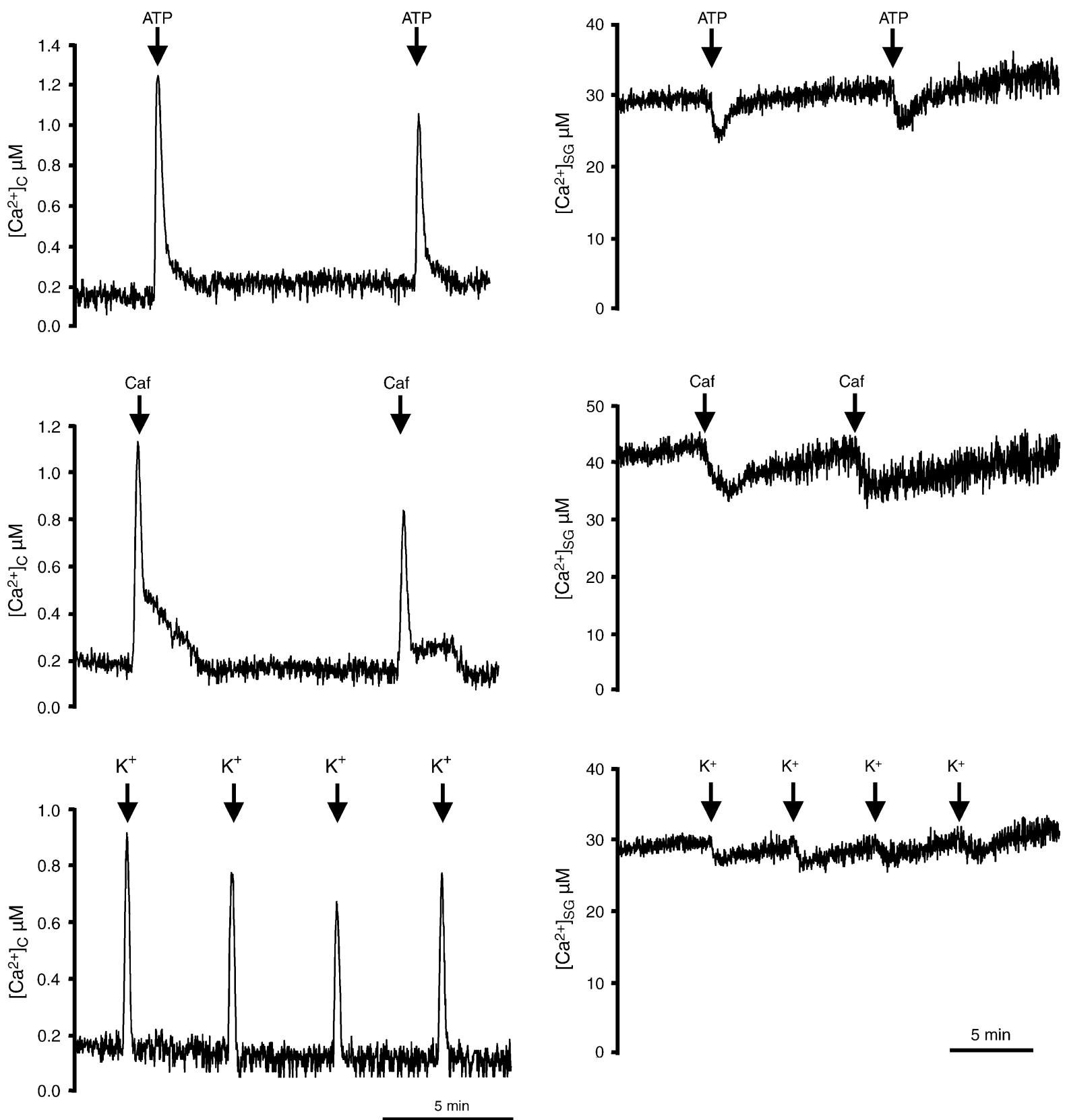

Fig. 3. Effects of ATP, caffeine and high- $\mathrm{K}^{+}$on both $\left[\mathrm{Ca}^{2+}\right]_{\mathrm{c}}$ and $\left[\mathrm{Ca}^{2+}\right]_{\mathrm{SG}}$. PC12 cells were transfected with either cytosolic aequorin (left panels) or VAMP-aequorin (right panels), and reconstituted with coelenterazine as described in Section 2. The left panels show the cytosolic $\left[\mathrm{Ca}^{2+}\right]$ peaks induced by $1 \mathrm{~min}$ stimulation with $100 \mu \mathrm{M}$ ATP or $10 \mathrm{mM}$ caffeine, or $30 \mathrm{~s}$ stimulation with a solution containing $70 \mathrm{mM} \mathrm{K}^{+}$. The right panels show the effect of the same stimuli on $\left[\mathrm{Ca}^{2+}\right]_{\mathrm{SG}}$. These experiments are representative of 5-10 similar ones of each kind.

to mimic local increases in the $\left[\mathrm{Ca}^{2+}\right]$ around the vesicles had no effect on $\left[\mathrm{Ca}^{2+}\right]_{\mathrm{SG}}$. Therefore, these second messengers are apparently not involved in the mechanism of the decrease in $\left[\mathrm{Ca}^{2+}\right]_{S G}$ induced by the agonists.

Regarding alternative $\mathrm{Ca}^{2+}$ transport systems in the granules, the presence of either $\mathrm{Ca}^{2+}$-ATPases, $\mathrm{Na}^{+} / \mathrm{Ca}^{2+}$ or $\mathrm{H}^{+} / \mathrm{Ca}^{2+}$ exchange systems have been proposed in different preparations [14-18]. Inhibition of sarcoendoplasmic reticulum $\mathrm{Ca}^{2+}$-ATPase with $10 \mu \mathrm{M}$ benzohydroquinone produced little effects on $\left[\mathrm{Ca}^{2+}\right]_{\mathrm{SG}}$ (data not shown), suggesting that this type of $\mathrm{Ca}^{2+}$-ATPase was not involved. On the other hand, in experiments performed with permeabilized cells, changes in the concentration of $\mathrm{Na}^{+}$ion from 10 to $0 \mathrm{mM}$ or from 10 to $140 \mathrm{mM}$ produced also no change in the $\left[\mathrm{Ca}^{2+}\right]_{\mathrm{SG}}$ (data not shown), suggesting that $\mathrm{Na}^{+} / \mathrm{Ca}^{2+}$ exchange is not operating in these granules. Instead, changes in the $\mathrm{pH}$ in the cytosolic side of the vesicles induced fast and reversible changes in $\left[\mathrm{Ca}^{2+}\right]_{\mathrm{SG}}$ consistent with the operation of a $\mathrm{H}^{+} / \mathrm{Ca}^{2+}$ exchange system. Fig. 5 shows experiments performed in permeabilized $\mathrm{PC} 12$ cells perfused with 


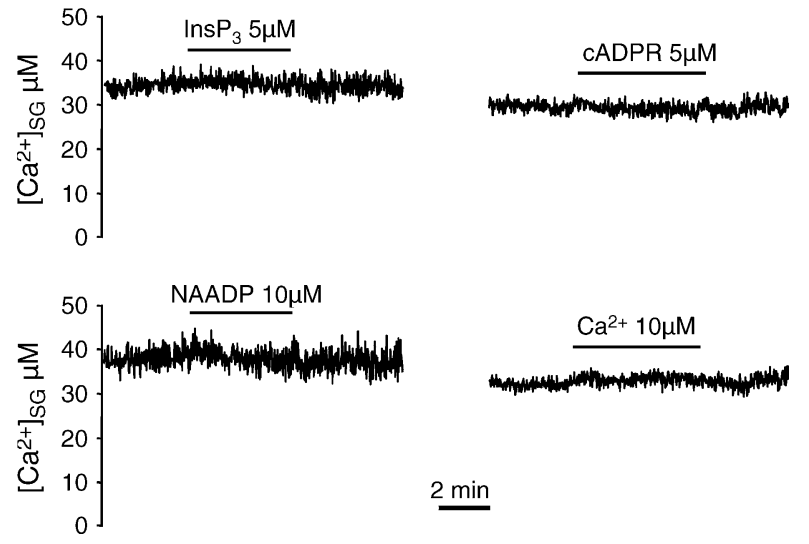

Fig. 4. Effect of $\mathrm{InSP}_{3}$, cADPR, NAADP and $\mathrm{Ca}^{2+}$ on $\left[\mathrm{Ca}^{2+}\right]_{\mathrm{SG}}$. PC12 cells expressing VAMP-aequorin were reconstituted with coelenterazine $\mathrm{n}$ and permeabilized with digitonin as described in Section 2 immediately prior to the experiment. Then, the effects of either $5 \mu \mathrm{M} \operatorname{InsP}_{3}, 5 \mu \mathrm{M}$ cADPR, $10 \mu \mathrm{M}$ NAADP or $10 \mu \mathrm{M} \mathrm{Ca}^{2+}$ were tested, as indicated. These experiments are representative of five similar ones of each kind.

buffers containing $100 \mathrm{nM}\left[\mathrm{Ca}^{2+}\right]$ and different $\mathrm{pH}$. It can be observed that a decrease in $\mathrm{pH}$ from 7.0 to 6.6 induced a decrease in $\left[\mathrm{Ca}^{2+}\right]_{\mathrm{SG}}$ from $40 \mu \mathrm{M}$ to below $30 \mu \mathrm{M}$, reversible after returning the cytosolic $\mathrm{pH}$ to 7.0. Vice versa, an increase in $\mathrm{pH}$ from 7.0 to 7.4 induced an increase in $\left[\mathrm{Ca}^{2+}\right]_{\mathrm{SG}}$ from $40 \mu \mathrm{M}$ to more than $50 \mu \mathrm{M}$, reversible after returning to $\mathrm{pH}$ 7.0. The effects of nigericin, an ionophore that catalizes $\mathrm{H}^{+} / \mathrm{K}^{+}$exchange, were also consistent with the presence of a $\mathrm{H}^{+} / \mathrm{Ca}^{2+}$ exchange. Fig. 5 (lower panel) shows that nigericin induced a decrease in $\left[\mathrm{Ca}^{2+}\right]_{\mathrm{SG}}$, which was reversible after washing the ionophore with a $0.1 \%$ albumin containing solution.

The decrease in $\left[\mathrm{Ca}^{2+}\right]_{\mathrm{SG}}$ induced by ATP, caffeine and high- $\mathrm{K}^{+}$could be also mediated by a vesicular $\mathrm{H}^{+} / \mathrm{Ca}^{2+}$ antiporter in case these stimuli induce a cytosolic acidification. This was the case. Fig. 6 shows the mean response of all the cells present under the microscope field in experiments performed with each agonist. Most of the cells responded to the stimuli with a transient or prolonged acidification and the mean response was in all the cases an acidification of around $0.1 \mathrm{pH}$ unit.

Fig. 7 (upper panel) shows that the protonophore FCCP produced also a decrease in $\left[\mathrm{Ca}^{2+}\right]_{\mathrm{SG}}$, which was reversible after washing the ionophore. The effect of FCCP is again consistent with the presence of $\mathrm{a} \mathrm{H}^{+} / \mathrm{Ca}^{2+}$ exchange operating in the membrane of the secretory granules. In case this system was responsible for the accumulation of $\mathrm{Ca}^{2+}$ into the vesicles, we reasoned that the reversibility of the effect of FCCP on $\left[\mathrm{Ca}^{2+}\right]_{S G}$ should depend on the restoration of the vesicular $\mathrm{H}^{+}$gradient via the bafilomycin-sensitive vacuolar $\mathrm{H}^{+}$-ATPase. However, as shown in the lower panel of Fig. 7, bafilomycin had no effect on this process. Similarly, incubation with $200 \mathrm{nM}$ bafilomycin for $15 \mathrm{~min}$ produced no effect on the resting $\left[\mathrm{Ca}^{2+}\right]_{\mathrm{SG}}$ (data not shown).

Therefore, restoration of the vesicular $\mathrm{H}^{+}$gradient was not required to revert the changes in $\left[\mathrm{Ca}^{2+}\right]_{\mathrm{SG}}$ induced by
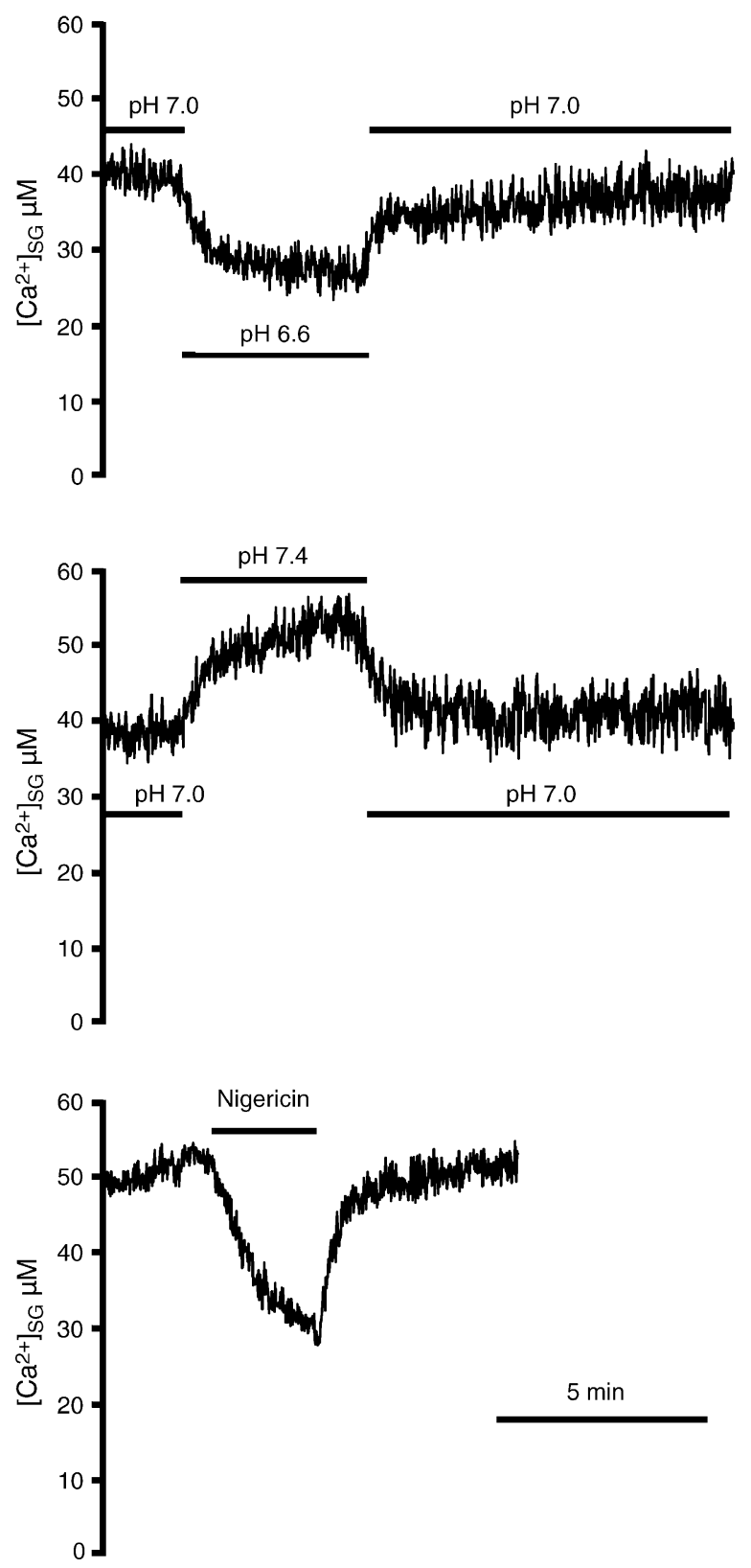

Fig. 5. Effect of $\mathrm{pH}$ changes and nigericin on $\left[\mathrm{Ca}^{2+}\right]_{\mathrm{SG}}$. PC12 cells expressing VAMP-aequorin were reconstituted with coelenterazine $\mathrm{n}$. In the upper and medium panels, they were also permeabilized with digitonin as described in Section 2 immediately prior to the experiment. Then, solutions containing $100 \mathrm{nM} \mathrm{Ca}^{2+}$ and the different $\mathrm{pH}$ indicated in the figure were perfused. In the lower panel, intact PC12 cells were treated with $2 \mu \mathrm{M}$ nigericin as indicated. The ionophore was then washed by perfusing medium containing $0.1 \%$ bovine serum albumin. These experiments are representative of four to eight similar ones of each kind.

FCCP. Alternatively, the presence of P-type $\mathrm{Ca}^{2+}$-ATPases, as suggested for the insulin containing vesicles of MIN6 $\beta$ cells [8], cannot be excluded. To obtain further evidence on this point, we perfused intracellular medium containing ADP (and $5 \mu \mathrm{M}$ oligomycin to abolish internal ATP production) instead of ATP in permeabilized cells, but we did not observe any changes in $\left[\mathrm{Ca}^{2+}\right]_{\mathrm{SG}}$. In addition, Fig. 8 (upper and 


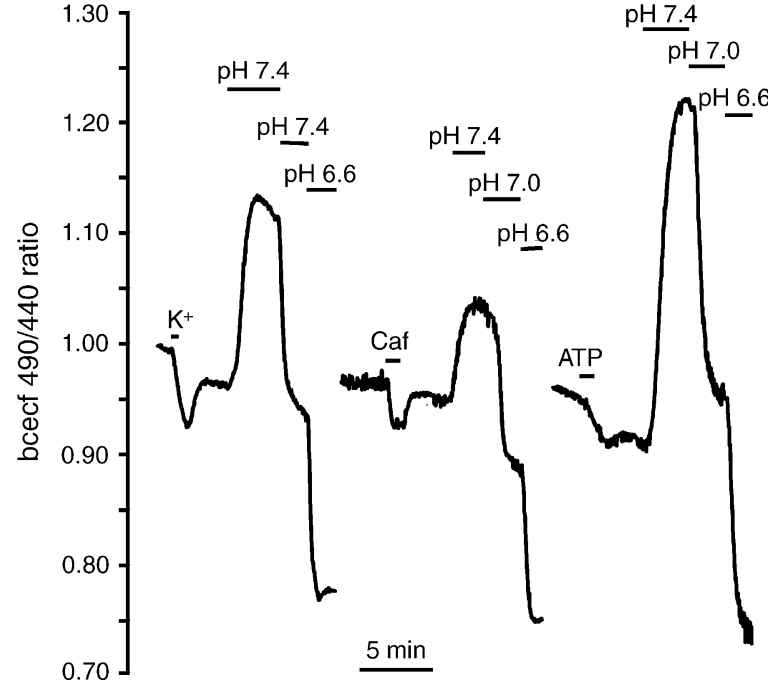

Fig. 6. Effects of ATP, caffeine and high- $\mathrm{K}^{+}$on cytosolic $\mathrm{pH}$. PC12 cells were loaded with beeff as described in Section 2 and then stimulated with either $100 \mu \mathrm{M}$ ATP for $1 \mathrm{~min}, 10 \mathrm{mM}$ caffeine for $1 \mathrm{~min}$ or with a solution containing $70 \mathrm{mM} \mathrm{K}^{+}$for $30 \mathrm{~s}$, as indicated in the figure. Traces shown correspond to the mean of all the cells present under the microscope field (high- $\mathrm{K}^{+}, 20$ cells; caffeine, 19 cells; ATP, 40 cells). These experiments are representative of at least three separate experiments of each kind.
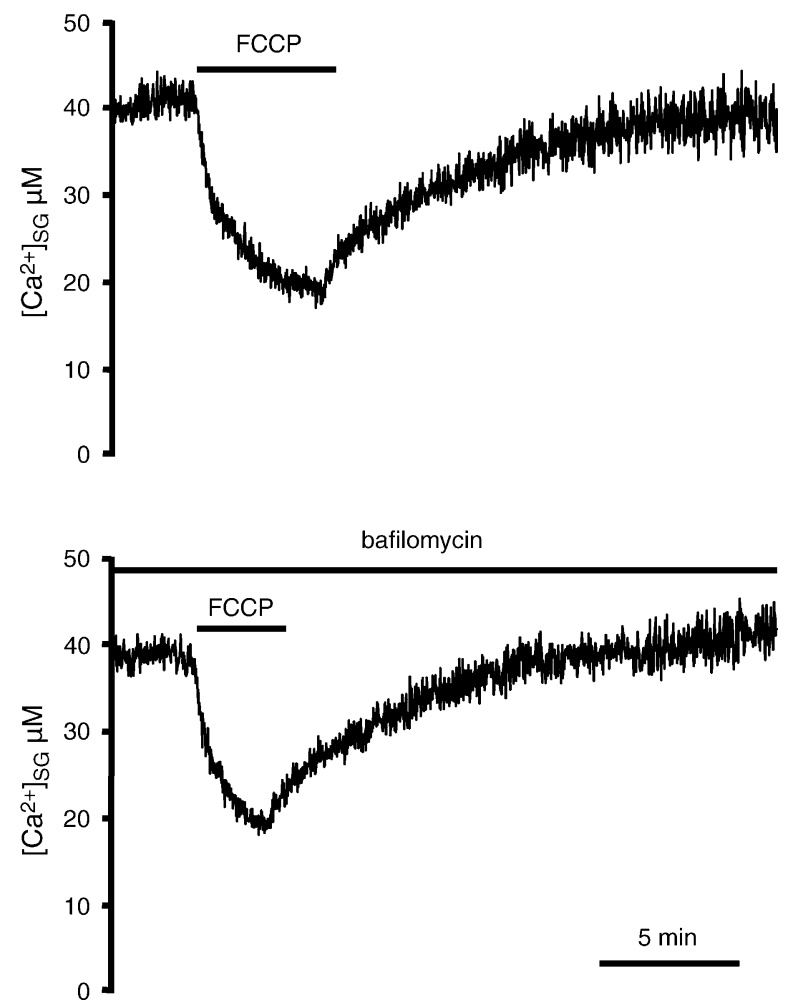

Fig. 7. Effect of FCCP on $\left[\mathrm{Ca}^{2+}\right]_{\mathrm{sG}}$. PC12 cells expressing VAMP-aequorin were reconstituted with coelenterazine $\mathrm{n}$ as described in Section 2. Then, $2 \mu \mathrm{M}$ FCCP was perfused as indicated. In the lower panel, $200 \mathrm{nM}$ bafilomycin was also present before, during and after FCCP addition, as indicated. These experiments are representative of six similar ones of each kind.
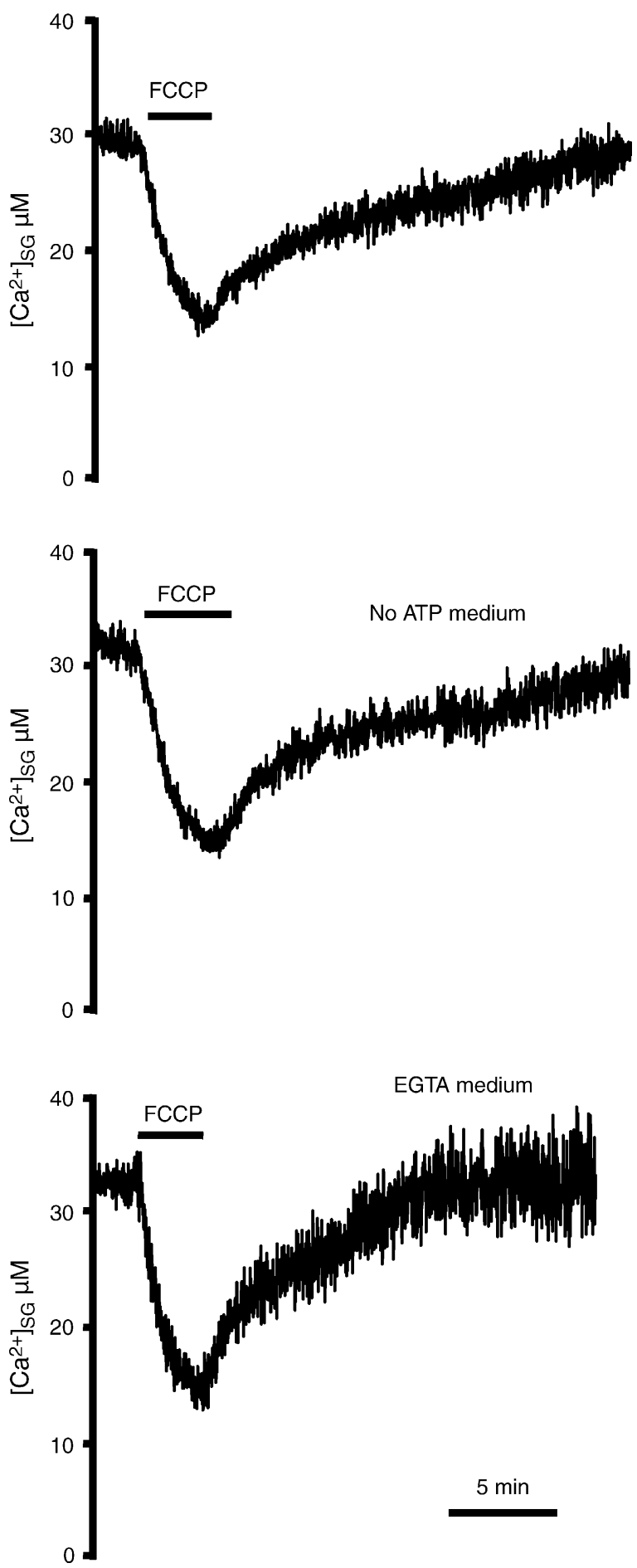

Fig. 8. Effect of FCCP on $\left[\mathrm{Ca}^{2+}\right]_{\mathrm{SG}}$ in permeabilized cells. PC12 cells expressing VAMP-aequorin were reconstituted with coelenterazine $\mathrm{n}$ and permeabilized with digitonin as described in Section 2 immediately prior to the experiment. Then, in the upper and medium panels, solutions containing $100 \mathrm{nM} \mathrm{Ca}^{2+}$ and either standard intracellular medium containing $1 \mathrm{mM}$ ATP (upper panel) or intracellular medium containing $1 \mathrm{mM}$ ADP and $5 \mu \mathrm{M}$ oligomycin instead of ATP (medium panel) were perfused. In the lower panel, standard intracellular medium containing $2 \mathrm{mM}$ EGTA and no $\mathrm{Ca}^{2+}$ was perfused. When indicated, $2 \mu \mathrm{M}$ FCCP was perfused in the same medium used for each experiment. These experiments are representative of three to five similar ones of each kind. 
medium panels) shows that the recovery from the $\left[\mathrm{Ca}^{2+}\right]_{\mathrm{SG}}$ decrease induced by FCCP occurred similarly in permeabilized cells perfused with medium with or without ATP, suggesting that ATP hydrolysis was also not necessary to restore the $\left[\mathrm{Ca}^{2+}\right]_{\mathrm{SG}}$ levels. Finally, Fig. 8 (lower panel) shows that recovery of $\left[\mathrm{Ca}^{2+}\right]_{\mathrm{SG}}$ after FCCP action took place unmodified even in permeabilized cells perfused with medium in the absence of $\mathrm{Ca}^{2+}$ (EGTA $2 \mathrm{mM}$ ).

\section{Discussion}

We show in this paper dynamic measurements of $\left[\mathrm{Ca}^{2+}\right]$ in the catecholamine-containing secretory granules of $\mathrm{PC} 12$ cells using a VAMP-aequorin chimera. Regarding the quality of the targeting to the secretory granules, we provide functional evidence that our probe (at least that able to reconstitute with coelenterazine $\mathrm{n}$ in the absence of $\mathrm{Ca}^{2+}$-depletion) is more than $95 \%$ located in a compartment containing around $40 \mu \mathrm{M}\left[\mathrm{Ca}^{2+}\right]$ under steady-state conditions. No other subcellular compartment known has $\left[\mathrm{Ca}^{2+}\right]$ levels in this range. Endoplasmic reticulum and Golgi apparatus have $\left[\mathrm{Ca}^{2+}\right] 5-10-$ fold higher [19,20], while cytosol, nucleus and mitochondria stay under resting conditions at $\left[\mathrm{Ca}^{2+}\right]$ below $1 \mu \mathrm{M}$. Our data of resting $\left[\mathrm{Ca}^{2+}\right]_{\mathrm{SG}}$ are consistent with those obtained with the same probe in MIN6 $\beta$-cells (around $50 \mu \mathrm{M}$, see ref [8]) and confirm that secretory granules are the organelle with the largest bound/free $\mathrm{Ca}^{2+}$ relationship. Estimations for the total calcium content of secretory granules in chromaffin or PC12 cells range between 20 and $40 \mathrm{mM}[3,21]$. Most of this $\mathrm{Ca}^{2+}$ must be bound to proteins such as chromogranin A, the major intravesicular protein of adrenal chromaffin granules. This protein, which constitutes $40 \%$ of the soluble intravesicular proteins [22], is known to bind $152 \mathrm{nmol}$ of $\mathrm{Ca}^{2+} / \mathrm{mg}$ of protein with a $K_{\mathrm{d}}$ of $54 \mu \mathrm{M}$, apart of several additional low affinity (millimolar) binding sites $[4,21,23]$. Given that the free $\left[\mathrm{Ca}^{2+}\right]_{S G}$ is around $40 \mu \mathrm{M}$, only the high affinity sites can bind significant amounts of $\mathrm{Ca}^{2+}$. In addition, a significant proportion of $\mathrm{Ca}^{2+}$ must be bound to ATP, as chromaffin granules may contain up to $130 \mathrm{mM}$ ATP [2].

The rapid release of $\mathrm{Ca}^{2+}$ from the secretory vesicles induced by the different agonists suggests that $\mathrm{Ca}^{2+}$ release from the granules during cell stimulation could play a role in secretion, in particular if the observed global decrease in $\left[\mathrm{Ca}^{2+}\right]_{\mathrm{SG}}$ induced by the agonists could be restricted to a small population of vesicles undergoing larger changes in their $\left[\mathrm{Ca}^{2+}\right]$. However, none of the known second messengers tested ( $\mathrm{InsP}_{3}, \mathrm{cADPR}, \mathrm{NAADP}$ or $\mathrm{Ca}^{2+}$ ) produced any effect on $\left[\mathrm{Ca}^{2+}\right]_{S G}$ in permeabilized cells. Thus, unless additional cellular components (perhaps lost during permeabilization) may be required, our data suggest that neither $\mathrm{InsP}_{3}$ receptors nor ryanodine receptors (at least those activated by cADPR or $\mathrm{Ca}^{2+}$ ) or NAADP-activated channels are involved in the mechanism of agonist-induced $\mathrm{Ca}^{2+}$ release from PC12 secretory granules.
Our data show also that changes in the $\mathrm{pH}$ gradient between the cytosol and the secretory granules immediately trigger changes in $\left[\mathrm{Ca}^{2+}\right]_{\mathrm{SG}}$ that are consistent with the operation of a $\mathrm{H}^{+} / \mathrm{Ca}^{2+}$ exchange. These effects cannot be attributed to the effects of intragranular $\mathrm{pH}$ changes in aequorin luminescence, because aequorin is little sensitive to $\mathrm{pH}$ in this range [8]. In addition, it should be remarked that both low $\mathrm{pH}$ and nigericin or FCCP induced decreases in $\left[\mathrm{Ca}^{2+}\right]_{\mathrm{SG}}$ (Fig. 5), although their effects in intragranular $\mathrm{pH}$ should be opposite. $\Delta \mathrm{pH}$-dependent $\mathrm{Ca}^{2+}$ fluxes thus appear to be the only mechanism able to generate fast changes in $\left[\mathrm{Ca}^{2+}\right]_{S G}$ under our conditions, and could be responsible of agonist-induced $\mathrm{Ca}^{2+}$ release from the granules. We show here that cell stimulation with ATP, caffeine or high- $\mathrm{K}^{+}$induces a transient acidification of the cytosol of about $0.1 \mathrm{pH}$ unit. It is difficult to assess if this acidification is enough to induce the measured decreases in $\left[\mathrm{Ca}^{2+}\right]_{\mathrm{SG}}$, but obviously the changes go in the right direction. In addition, local $\mathrm{pH}$ changes in the vicinity of the secretory granules close to the plasma membrane may be larger than the global changes measured here. Consistently, it has been shown that stimulation of PC12 cells with high$\mathrm{K}^{+}$depolarization induces alcalinization of secretory vesicles [24]. A similar finding has been described in mast cells [25]. Operation of a $\mathrm{H}^{+} / \mathrm{Ca}^{2+}$ exchange has been previously described in synaptic vesicles [18,26] and yeast vacuoles [27].

As mentioned above, our data in PC12 secretory granules share with those described in MIN6 $\beta$-cells $[8,9]$ the similar steady-state $\left[\mathrm{Ca}^{2+}\right]$ levels. However, there are many differences in the dynamics, such as the lack of effect of FCCP on MIN6 $\beta$-cells $\left[\mathrm{Ca}^{2+}\right]_{\mathrm{SG}}$, the increase in $\left[\mathrm{Ca}^{2+}\right]_{\mathrm{SG}}$ induced by an Ins $\mathrm{P}_{3}$-producing agonist in those cells and the release of $\mathrm{Ca}^{2+}$ from the MIN6 $\beta$-cells through both ryanodine receptors and NAADP receptors. On the contrary, none of these receptors appears to be present in the PC12 secretory vesicles and the protonophore $\mathrm{FCCP}$, the $\mathrm{H}^{+} / \mathrm{K}^{+}$exchange ionophore nigericine, and the different extracellular stimuli induced all of them rapid decreases of $\left[\mathrm{Ca}^{2+}\right]_{\mathrm{SG}}$ in PC12 cells. These differences probably result from the presence of a $\mathrm{H}^{+} / \mathrm{Ca}^{2+}$ exchange system in PC12 granules.

Regarding the mechanism of accumulation of $\mathrm{Ca}^{2+}$ into PC12 granules, our data on the restoration of $\left[\mathrm{Ca}^{2+}\right]_{\mathrm{SG}}$ levels after FCCP action are intriguing. In permeabilized cells, FCCP induced a decrease in $\left[\mathrm{Ca}^{2+}\right]_{\mathrm{SG}}$ that was completely reversible even in the absence of $\mathrm{Ca}^{2+}$ and ATP in the perfusion medium. The only explanation to these results would be the presence in the secretory granules of a large capacity, low affinity and slow-exchanging $\mathrm{Ca}^{2+}$ buffer, that would be able to release $\mathrm{Ca}^{2+}$ during the following 10-15 min after FCCP action to restore $\left[\mathrm{Ca}^{2+}\right]_{S G}$ levels in the absence of any $\mathrm{Ca}^{2+}$ influx from the cytosol. This possibility is consistent with previous data showing that calcium binds and precipitates chromogranins at affinities compatible with their physiological concentrations and that this tight binding could account for more than $90 \%$ of intravesicular calcium [28]. The picture that emerges now is that of a vesicle containing relatively small amounts of free or rapidly exchanging bound $\mathrm{Ca}^{2+}$ and 
a large store of tightly bound slow-exchanging $\mathrm{Ca}^{2+}$. Accordingly, disruption of the vesicular $\mathrm{pH}$ gradient with weak amines induces a very slow release of calcium from the vesicles, about $20 \%$ in 15 min [29]. The steady-state $\mathrm{Ca}^{2+}$ accumulation into the vesicles may be due to the operation of $\mathrm{H}^{+} / \mathrm{Ca}^{2+}$ exchange combined with the energy provided by the $\mathrm{H}^{+}$gradient generated by the vacuolar $\mathrm{H}^{+}$-ATPase. However, the presence of P-type $\mathrm{Ca}^{2+}$-ATPases cannot be excluded, and both systems could in fact coexist, as has been described in synaptic vesicles [30] and yeast vacuoles [27].

In conclusion, the main findings of this work are: (i) catecholamine-containing secretory granules have an homogeneous steady-state $\left[\mathrm{Ca}^{2+}\right]$ around $40 \mu \mathrm{M}$; (ii) cell stimulation by different mechanisms, either mediated by $\mathrm{InsP}_{3}$ receptors, ryanodine receptors or plasma membrane $\mathrm{Ca}^{2+}$ channels, induces a transient decrease in secretory granule $\left[\mathrm{Ca}^{2+}\right]$ that occurs simultaneously to the increase in cytosolic $\left[\mathrm{Ca}^{2+}\right]$; (iii) changes in cytosolic $\mathrm{pH}$ or abolition of the $\mathrm{pH}$ gradient between the cytosol and the granules induce rapid changes of $\left[\mathrm{Ca}^{2+}\right]$ in the secretory vesicles that are consistent with the operation of $\mathrm{A} \mathrm{H}^{+} / \mathrm{Ca}^{2+}$ antiporter in the vesicular membrane; (iv) reversibility of FCCP-induced $\left[\mathrm{Ca}^{2+}\right]_{S G}$ decrease occurs similarly either in the presence or in the absence of $\mathrm{Ca}^{2+}$ or ATP in the cytosol, suggesting the presence of a large and slow-exchanging $\mathrm{Ca}^{2+}$ buffer in the vesicle matrix. This large store of tightly bound calcium buffers $\left[\mathrm{Ca}^{2+}\right]_{\mathrm{SG}}$ changes in the long-term, but allows rapid changes in free $\left[\mathrm{Ca}^{2+}\right]_{S G}$ occurring in times of seconds or minutes. Secretory granules are therefore a much more dynamic organelle in terms of free $\left[\mathrm{Ca}^{2+}\right]_{\mathrm{SG}}$ than previously thought. The functional significance of these $\mathrm{Ca}^{2+}$ changes is still unknown, but evidence for a role of vesicular $\mathrm{Ca}^{2+}$ in exocytosis has been provided in several types of secretory vesicles [31-33].

A paper recently published by Mahapatra et al. [34] explores also the dynamics of $\left[\mathrm{Ca}^{2+}\right]$ in the secretory granules of PC12 cells using a chromogranin-aequorin chimeric protein. However, their results are largely different from ours both in terms of the free $\left[\mathrm{Ca}^{2+}\right]$ in the secretory granules (only $1.4 \mu \mathrm{M}$ ) and the response to different stimuli. The discrepancy is clearly due to the different $\mathrm{Ca}^{2+}$ affinity of the aequorin probes in both cases. Mahapatra et al. used an aequorin chimera with much higher $\mathrm{Ca}^{2+}$ affinity, which is unable to reconstitute with coelenterazine in areas where the $\left[\mathrm{Ca}^{2+}\right]$ is above a few micromolar. Thus, their measurements reflect the behavior of the small compartment (less than $5 \%$ of the total space) having low resting $\left[\mathrm{Ca}^{2+}\right]$ and functional properties completely different from those shown here for the bulk of the granular space. We have reported before similar discrepancies in the dynamics of $\left[\mathrm{Ca}^{2+}\right]$ in the endoplasmic reticulum using aequorin chimeras with different $\mathrm{Ca}^{2+}$ affinities [12].

\section{Acknowledgements}

This work was supported by grants from Dirección General de Enseñanza Superior (BFI2002-01397) and from Junta de Castilla y León (VA 005/02). J.S. and E.H.-S. hold FPI and FPU fellowships, respectively, from the Spanish Ministerio de Educación y Ciencia.

\section{References}

[1] F. Clemente, J. Meldolesi, Calcium and pancreatic secretiondynamics of subcellular calcium pools in resting and stimulated acinar cells, Br. J. Pharmacol. 55 (1975) 369-379.

[2] H. Winkler, E. Westhead, The molecular organization of adrenal chromaffin granules, Neuroscience 5 (1980) 1803-1823.

[3] C. Fasolato, M. Zottini, E. Clementi, D. Zacchetti, J. Meldolesi, T. Pozzan, Intracellular $\mathrm{Ca}^{2+}$ pools in $\mathrm{PC} 12$ cells. Three intracellular pools are distinguished by their turnover and mechanisms of $\mathrm{Ca}^{2+}$ accumulation, storage, and release, J. Biol. Chem. 266 (1991) 20159-20167.

[4] D. Bulenda, M. Gratzl, Matrix free $\mathrm{Ca}^{2+}$ in isolated chromaffin vesicles, Biochemistry 24 (1985) 7760-7765.

[5] T. Pozzan, R. Rizzuto, P. Volpe, J. Meldolesi, Molecular and cellular physiology of intracellular calcium stores, Physiol. Rev. 74 (1994) 595-636.

[6] G.A. Rutter, C. Fasolato, R. Rizzuto, Calcium and organelles: a twosided story, Biochem. Biophys. Res. Commun. 253 (1998) 549-557.

[7] S.H. Yoo, Coupling of the $\mathrm{IP}_{3}$ receptor/ $\mathrm{Ca}^{2+}$ channel with $\mathrm{Ca}^{2+}$ storage proteins chromogranins $\mathrm{A}$ and $\mathrm{B}$ in secretory granules, Trends Neurosci. 23 (2000) 424-428.

[8] K.J. Mitchell, P. Pinton, A. Varadi, C. Tacchetti, E.K. Ainscow, T. Pozzan, R. Rizzuto, G.A. Rutter, Dense core secretory vesicles revealed as a dynamic $\mathrm{Ca}^{2+}$ store in neuroendocrine cells with a vesicle-associated membrane protein aequorin chimaera, J. Cell Biol. 155 (2001) 41-51.

[9] K.J. Mitchell, F.A. Lai, G.A. Rutter, Ryanodine receptor type I and nicotinic acid adenine dinucleotide phosphate receptors mediate $\mathrm{Ca}^{2+}$ release from insulin-containing vesicles in living pancreatic beta-cells (MIN6), J. Biol. Chem. 278 (2003) 11057-11064.

[10] M. Brini, R. Marsault, C. Bastianutto, J. Alvarez, T. Pozzan, R. Rizzuto, Transfected aequorin in the measurement of cytosolic $\mathrm{Ca}^{2+}$ concentration $\left(\left[\mathrm{Ca}^{2+}\right]_{\mathrm{c}}\right)$. A critical evaluation, J. Biol. Chem. 270 (1995) 9896-9903.

[11] J. Alvarez, M. Montero, Measuring $\left[\mathrm{Ca}^{2+}\right]$ in the endoplasmic reticulum with aequorin, Cell Calcium 32 (2002) 251-260.

[12] M. Montero, J. Alvarez, W.J. Scheenen, R. Rizzuto, J. Meldolesi, T. Pozzan, $\mathrm{Ca}^{2+}$ homeostasis in the endoplasmic reticulum: coexistence of high and low $\left[\mathrm{Ca}^{2+}\right]$ subcompartments in intact HeLa cells, J. Cell Biol. 139 (1997) 601-611.

[13] M. Montero, M.T. Alonso, E. Carnicero, I. Cuchillo-Ibanez, A. Albillos, A.G. Garcia, J. Garcia-Sancho, J. Alvarez, Chromaffin-cell stimulation triggers fast millimolar mitochondrial $\mathrm{Ca}^{2+}$ transients that modulate secretion, Nat. Cell Biol. 2 (2000) 57-61.

[14] H. Krieger-Brauer, M. Gratzl, Uptake of $\mathrm{Ca}^{2+}$ by isolated secretory vesicles from adrenal medulla, Biochim. Biophys. Acta 691 (1982) $61-70$.

[15] H. Krieger-Brauer, M. Gratzl, Effects of monovalent and divalent cations on $\mathrm{Ca}^{2+}$ fluxes across chromaffin secretory membrane vesicles, J. Neurochem. 41 (1983) 1269-1276.

[16] J.D. Troadec, S. Thirion, J.P. Laugier, G. Nicaise, Calcium-induced calcium increase in secretory vesicles of permeabilized rat neurohypophysial nerve terminals, Biol. Cell. 90 (1998) 339-347.

[17] S. Thirion, J.D. Troadec, N.B. Pivovarova, S. Pagnotta, S.B. Andrews, R.D. Leapman, G. Nicaise, Stimulus-secretion coupling in neurohypophysial nerve endings: a role for intravesicular sodium? Proc. Natl. Acad. Sci. U.S.A. 96 (1999) 3206-3210.

[18] P.P. Goncalves, S.M. Meireles, C. Gravato, M.G. Vale, $\mathrm{Ca}^{2+}-\mathrm{H}^{+}$ antiport activity in synaptic vesicles isolated from sheep brain cortex, Neurosci. Lett. 247 (1998) 87-90. 
[19] M. Montero, M.J. Barrero, J. Alvarez, $\left[\mathrm{Ca}^{2+}\right]$ microdomains control agonist-induced $\mathrm{Ca}^{2+}$ release in intact HeLa cells, FASEB J. 11 (1997) 881-885.

[20] P. Pinton, T. Pozzan, R. Rizzuto, The Golgi apparatus is an inositol 1,4,5-trisphosphate-sensitive $\mathrm{Ca}^{2+}$ store, with functional properties distinct from those of the endoplasmic reticulum, EMBO J. 17 (1998) 5298-5308.

[21] S.H. Yoo, J.P. Albanesi, High capacity, low affinity $\mathrm{Ca}^{2+}$ binding of chromogranin A. Relationship between the $\mathrm{pH}$-induced conformational change and $\mathrm{Ca}^{2+}$ binding property, J. Biol. Chem. 266 (1991) $7740-7745$.

[22] J.P. Simon, D. Aunis, Biochemistry of the chromogranin A protein family, Biochem. J. 262 (1989) 1-13.

[23] F.U. Reiffen, M. Gratzl, $\mathrm{Ca}^{2+}$ binding to chromaffin vesicle matrix proteins: effect of $\mathrm{pH}, \mathrm{Mg}^{2+}$, and ionic strength, Biochemistry 25 (1986) 4402-4406.

[24] W. Han, D. Li, A.K. Stout, K. Takimoto, E.S. Levitan, $\mathrm{Ca}^{2+}$-induced deprotonation of peptide hormones inside secretory vesicles in preparation for release, J. Neurosci. 19 (1999) 900-905.

[25] R.M. Williams, W.W. Webb, Single granule $\mathrm{pH}$ cycling in antigeninduced mast cell secretion, J. Cell Sci. 113 (2000) 3839-3850.

[26] P.P. Goncalves, S.M. Meireles, P. Neves, M.G. Vale, Ionic selectivity of the $\mathrm{Ca}^{2+} / \mathrm{H}^{+}$antiport in synaptic vesicles of sheep brain cortex, Brain. Res. Mol. Brain Res. 67 (1999) 283-291.

[27] C. Ungermann, W. Wickner, Z. Xu, Vacuole acidification is required for trans-SNARE pairing, LMA1 release, and homotypic fusion, Proc. Natl. Acad. Sci. U.S.A. 96 (1999) 11194-11199.
[28] J.S. Videen, M.S. Mezger, Y.M. Chang, D.T. O'Connor, Calcium and catecholamine interactions with adrenal chromogranins. Comparison of driving forces in binding and aggregation, J. Biol. Chem. 267 (1992) 3066-3073.

[29] M.L. Mundorf, S.E. Hochstetler, R.M. Wightman, Amine weak bases disrupt vesicular storage and promote exocytosis in chromaffin cells, J. Neurochem. 73 (1999) 2397-2405.

[30] P.P. Goncalves, S.M. Meireles, P. Neves, M.G. Vale, Distinction between $\mathrm{Ca}^{2+}$ pump and $\mathrm{Ca}^{2+} / \mathrm{H}^{+}$antiport activities in synaptic vesicles of sheep brain cortex, Neurochem. Int. 37 (2000) 387396

[31] P. Fossier, M.F. Diebler, J.P. Mothet, M. Israel, L. Tauc, G. Baux, Control of the calcium concentration involved in acetylcholine release and its facilitation: an additional role for synaptic vesicles? Neuroscience 85 (1998) 85-91.

[32] W.J. Scheenen, C.B. Wollheim, T. Pozzan, C. Fasolato, $\mathrm{Ca}^{2+}$ depletion from granules inhibits exocytosis. A study with insulin-secreting cells, J. Biol. Chem. 273 (1998) 19002-19008.

[33] M.L. Mundorf, K.P. Troyer, S.E. Hochstetler, J.A. Near, R.M. Wightman, Vesicular $\mathrm{Ca}^{2+}$ participates in the catalysis of exocytosis, J. Biol. Chem. 275 (2000) 9136-9142.

[34] N.R. Mahapatra, M. Mahata, P.P. Hazra, P.M. McDonough, D.T. O'Connor, S.K. Mahata, A dynamic pool of calcium in catecholamine storage vesicles: exploration in living cells by a novel vesicle-targeted chromogranin A/aequorin chimeric photoprotein, J. Biol. Chem. 279 (2004) 51107-51121. 